\title{
Effects of tributyltin exposure in the embryonic stage on sex ratio and survival rate in the caprellid amphipod Caprella danilevskii
}

\author{
Madoka Ohji*, Takaomi Arai, Nobuyuki Miyazaki \\ Otsuchi Marine Research Center, Ocean Research Institute, The University of Tokyo, 2-106-1, Akahama, \\ Otsuchi, Iwate 028-1102, Japan
}

\begin{abstract}
In order to examine the biological effects of tributyltin (TBT) exposure, the caprellid amphipod Caprella danilevskii was exposed to 5 levels (0,10,100, 1000 and $10000 \mathrm{ng} \mathrm{l}^{-1}$ ) of TBT during the embryonic stage $(5 \mathrm{~d})$. The male and female ratios changed dramatically in the hatched juvenile with increases in TBT concentrations; i.e. the proportion of females was found to increase to $55.6 \%$ at $10 \mathrm{ng} \mathrm{l}^{-1}, 85.7 \%$ at $100 \mathrm{ng} \mathrm{l}^{-1}$ and $81.8 \%$ at $1000 \mathrm{ng} \mathrm{l}^{-1}$. All specimens died in $10000 \mathrm{ng}$ TBTCl $\mathrm{l}^{-1}$ within $5 \mathrm{~d}$ after spawning due to the acute toxic concentration for the species. No significant differences were observed to occur in the sex ratio in response to the exposure after hatching (50 d) in a previous study. Sex disturbance might therefore be induced during the embryonic stage in the caprellid. Reproductive inhibitions such as brood loss and oogenesis inhibition occurred even at 10 to $100 \mathrm{ng}$ TBTCl $\mathrm{l}^{-1}$ exposures in the short term in both parental females and their offspring females. The survival rate decreased drastically as the TBT concentrations increased, with the decrease being observed at TBT concentrations as low as $10 \mathrm{ng} \mathrm{l}^{-1}(69 \%)$ in the offspring. In parental females, the survival rate also decreased at more than $100 \mathrm{ng} \mathrm{TBTCl} \mathrm{l}^{-1}$, despite movement after $5 \mathrm{~d}$ into the no-TBT-added seawater. Therefore, our data suggest that nanogram concentrations of TBT similar to those encountered in coastal waters can directly affect sex ratio, reproduction and survival in the caprellid, and this phenomenon occurs at environmentally realistic concentrations in the coastal ecosystem.
\end{abstract}

KEY WORDS: Tributyltin $\cdot$ Caprellid $\cdot$ Sex ratio $\cdot$ Survival rate $\cdot$ Reproduction

\section{INTRODUCTION}

In organotin compounds, it has recently become clear that antifouling chemicals with biocide properties such as those of tributyltin (TBT) exert adverse effects on environmental components of the marine ecosystem. TBT accumulation in the marine ecosystem along the food chain is different from that of other chemicals, i.e. no significant biomagnification is observed in the higher levels of the food chain (Takahashi et al. 1999). However, high concentrations have been found in lower trophic organisms such as caprellids because of

*E-mail: ohji@wakame.ori.u-tokyo.ac.jp their lower metabolic capacity to degrade TBT, causing them to accumulate butyltins (BTs) at elevated concentrations (Takahashi et al. 1999, Ohji et al. 2002).

Caprellids are an important trophic link as one of the dominant secondary producers between unicellular algae and fishes in coastal water ecosystem. Furthermore, these organisms are important prey resources for small fishes in coastal ecosystem (Fuse 1962, Caine 1989, Holbrook \& Schmitt 1992). Recently, the use of caprellids in monitoring temporal and spatial changes in baseline concentrations of BTs has been proposed (Takeuchi et al. 2001, Ohji et al. 2002). However, little information is available regarding the biological effects in relation to sex ratio, survival rate, growth rate and reproduction as a function of BTs exposure. Such 
verification is likely a prerequisite to understanding the biological impacts of chemical toxicants as well as the interpretation of the BTs accumulation process in the coastal ecosystem.

The objectives of the present study were to examine the biological effects of TBT exposure during the embryonic stage of the caprellid amphipod Caprella danilevskii Czerniavski. The results form the basis of discussions on the fluctuation of abundance of this species in the coastal ecosystem as well as the biological impact of TBT on it.

\section{MATERIALS AND METHODS}

Specimens, seawater and TBT solution. Caprella danilevskii was collected from the rocky shore in Uchiura Bay, central Japan. Premature females and mature males were sorted and provided for the experiments.

The seawater used for the present experiments was collected from a depth of $10 \mathrm{~m}$ outside Otsuchi Bay, NE Japan, where TBT concentrations at 0.5 and $10 \mathrm{~m}$ depths were confirmed to be less than the detection limit (Takahashi et al. 1999, Ohji et al. 2002).

A TBT-seawater solution and the control seawater were made following Ohji et al. (2002). In the present study, 5 test concentrations of TBTCl $(0,10,100,1000$ and $10000 \mathrm{ng} \mathrm{l}^{-1}$ ) were prepared using dilute solution. These solutions were made every week.

Embryonic exposure experiments. After reaching the mature stage, these parental females were allowed to copulate with males, and spawning was stimulated (first mature stage in parent). After spawning in the brood pouch, ovigerous mature females were transferred to Petri dishes containing each concentration of $\mathrm{TBTCl}$, respectively. One ovigerous mature female was allocated per dish, and a total of 11 females were used for the exposure experiment (55 females in 5concentration exposure experiments). The conditions of ovigerous parental females and egg number in the brood pouch were observed each day. The rearing method was otherwise the same as that described by M. Ohji et al. (unpubl.).

Specimens were exposed to 5 concentrations of TBTCl for $5 \mathrm{~d}$, which corresponded to the period of embryonic development. After being released from the brood pouch, the juveniles were transferred into the filtered seawater containing neither TBTCl nor acetone. Two juveniles were allocated per dish, and a total of 11 to 25 specimens were used for the exposure experiment (68 juveniles in 5 exposure experiments).

Furthermore, parental females were transferred to the filtered seawater. After molting, these females were recopulated. After spawning (second mature stage in parent), the eggs were counted at each concentration of TBTCl to examine the effects of TBTCl on the oogenesis stage.

After the TBTCl-exposed female juveniles reached maturity, they were allowed to copulate with males, and spawned (first generation of offspring). The eggs were counted each day. After juveniles were released, these juveniles continued to rear until instar II, and the sex was determined (second generation of offspring). The specimens that survived over $50 \mathrm{~d}$ or died during the experimental period were fixed with $10 \%$ formalin.

Statistical analysis. Comparisons of life span between the control condition ( $0 \mathrm{ng} \mathrm{TBTCl} \mathrm{l}^{-1}$ ) and each concentration $\left(0,10,100,1000\right.$ and $\left.10000 \mathrm{ng} \mathrm{l}^{-1}\right)$ of TBTCl were carried out by the log-rank test. A comparison of sex ratio between the control and each concentration of TBTCl was carried out by the chi-squared test. Differences in both reproduction and growth between the control and each concentration of TBTCl were tested by the Mann-Whitney $U$-test. Comparisons between the number of eggs spawned and number of juveniles hatched, and between the number of eggs spawned in the first mature stage and the number of eggs spawned in the second mature stage in the parental female were carried out by Wilcoxon's signed-rank test. All statistical analyses were carried out by StatView 5.0 (SAS Institute).

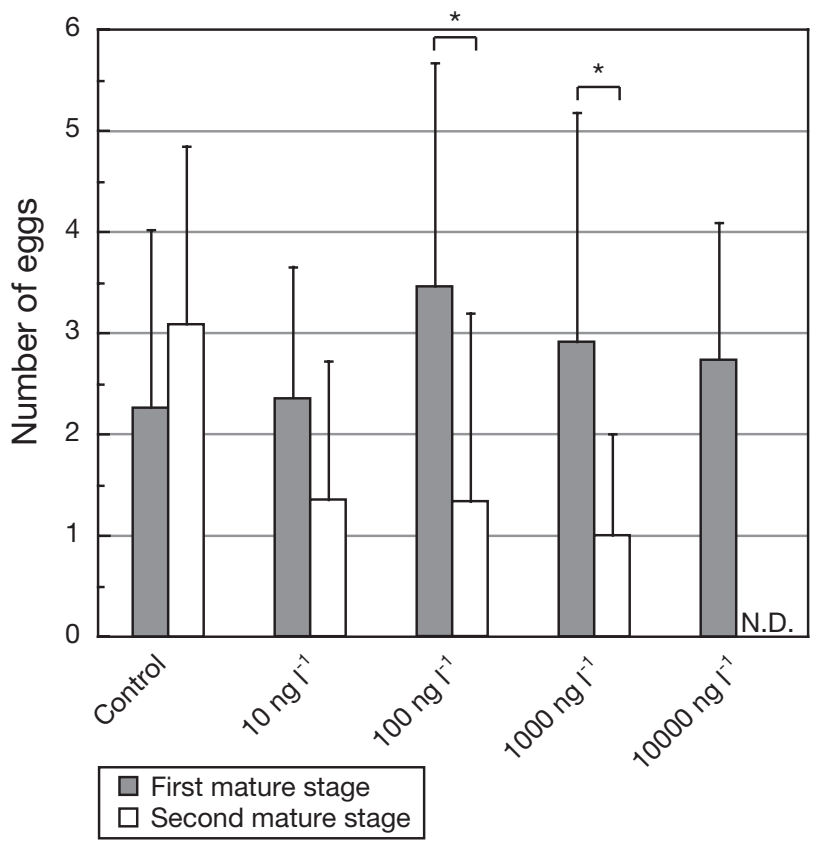

Fig. 1. Comparison of the number of eggs released into the brood pouch between the first and second mature stages in the parental female. N.D.: no data because of death of all specimens. Wilcoxon's signed-rank test, * $\mathrm{p}<0.05$ 


\section{RESULTS}

\section{Condition of parental females}

Eleven ovigerous females were allocated to each concentration compartment of TBTCl $(0,10,100,1000$ and $10000 \mathrm{ng} \mathrm{l}^{-1}$ ). The average ( \pm standard deviation [SD]) number of eggs of the females ranged from $2.3 \pm 1.7$ to $3.5 \pm 2.2$ in the brood pouch (Fig. 1). No significant differences were found in the number of eggs spawned between the control and the other 4 concentrations of TBTCl (Mann-Whitney $U$-test, p > 0.1). Some deaths of ovigerous females exposed for $5 \mathrm{~d}$ were observed at more than $100 \mathrm{ng} \mathrm{TBTCl}^{-1}$, and all specimens died at $10000 \mathrm{ng} \mathrm{TBTCl}^{-1}$ due to the acute toxic concentration for the species (Ohji et al. 2002) (Fig. 2). Brood loss of the females also occurred at concentrations higher than $10 \mathrm{ng} \mathrm{TBTCl} \mathrm{l}^{-1}$, ranging from 3 to 6 specimens, while no brood loss was observed in the control ( 0 ng TBTCl $\left.\mathrm{l}^{-1}\right)$.

The average number of eggs spawned in the brood pouch in the second mature stage ranged from $1.0 \pm$ 1.0 to $3.1 \pm 1.8$ (Fig. 1). Significant differences were found in the number of eggs between the control and 3 concentrations $\left(10,100\right.$ and $\left.1000 \mathrm{ng} \mathrm{l}^{-1}\right)$ of $\mathrm{TBTCl}$ (Mann-Whitney $U$-test, $\mathrm{p}<0.05$ to $\mathrm{p}<0.01$ ). Furthermore, significant differences in the number of eggs were found between the first and second mature stages at $100 \mathrm{ng}$ TBTCl $\mathrm{l}^{-1}$ and $1000 \mathrm{ng} \mathrm{TBTCl} \mathrm{l^{-1 }}$ (Wilcoxon's signed-rank test, p < 0.05) (Fig. 1).

\section{Survival rate in the first generation of offspring}

The survival rate (estimated from the amount of brood loss, the number of eggs in the brood pouch in

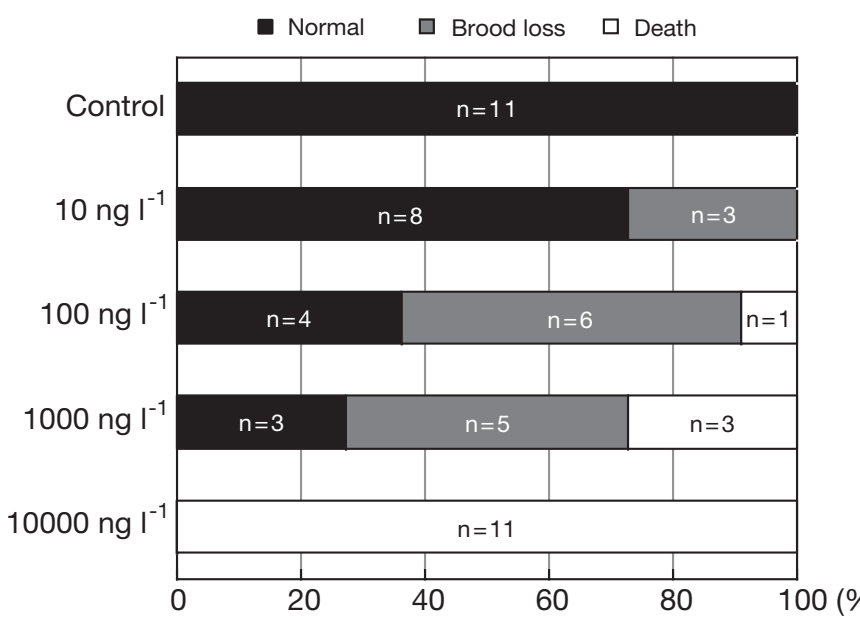

Fig. 2. Condition of the parental female in the first mature stage after $5 \mathrm{~d}$ exposure to tributyltin chloride (TBTCl)

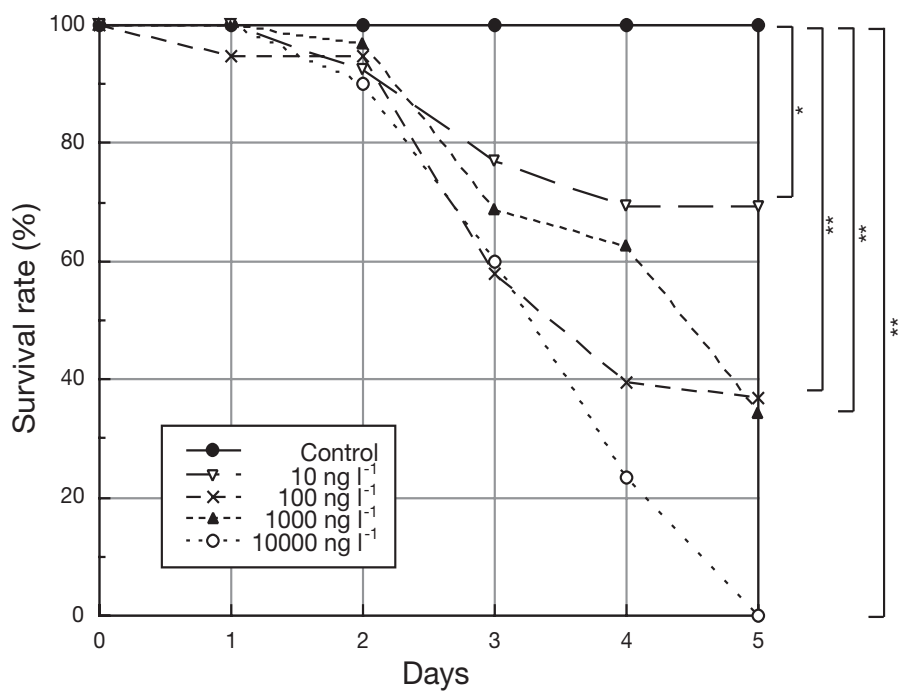

Fig. 3. Changes in the survival rate in embryos exposed to TBTCl during the embryonic stage (5 d). Log-rank test, ${ }^{*} \mathrm{p}<0.05,{ }^{* *} \mathrm{p}<0.0001$

dead specimens and the total number of eggs) during the TBTCl exposure period decreased as the TBTCl concentrations increased, i.e. $69.2 \%$ at $10 \mathrm{ng} \mathrm{l}^{-1}, 36.8 \%$ at $100 \mathrm{ng} \mathrm{l}^{-1}, 34.4 \%$ at $1000 \mathrm{ng} \mathrm{l}^{-1}$ and $0 \%$ at $10000 \mathrm{ng} \mathrm{l}^{-1}$ (Fig. 3). Significant differences were found in the survival rates between the control and the other 4 concentrations (log-rank test, $\mathrm{p}<0.05$ to $\mathrm{p}<0.0001$ ).

The number of juveniles hatched decreased as the TBTCl concentrations increased, i.e. $2.3 \pm 1.7$ in the control, $1.6 \pm 1.6$ at $10 \mathrm{ng} \mathrm{l}^{-1}, 1.3 \pm 1.9$ at $100 \mathrm{ng} \mathrm{l}^{-1}$, $1.0 \pm 1.3$ at $1000 \mathrm{ng} \mathrm{l}^{-1}$ and 0 at $10000 \mathrm{ng} \mathrm{l}^{-1}$ (Fig. 4). Significant differences were found between the control and $1000 \mathrm{ng} \mathrm{TBTCl}^{-1}$ and between the control and $10000 \mathrm{ng}$ TBTCl $\mathrm{l}^{-1}$ (Mann-Whitney $U$-test, $\mathrm{p}<0.05$ to $\mathrm{p}<0.0001)$. Furthermore, significant differences were found between the number of eggs spawned in the brood pouch and the number of juveniles hatched at $100 \mathrm{ng} \mathrm{TBTCl} \mathrm{l} \mathrm{T}^{-1}, 1000 \mathrm{ng}$ TBTCl l $\mathrm{l}^{-1}$ and $10000 \mathrm{ng}$ TBTCl $\mathrm{l}^{-1}$ (Wilcoxon's signed-rank test, $\mathrm{p}<0.05$ to $\mathrm{p}<0.01$ ) (Fig. 4).

At all concentrations, the survival rate in offspring continued to decrease despite the movement of hatched juveniles into seawater that did not contain either TBTCl or acetone (Fig. 5). Significant differences were found in the survival rate between the control and the other 4 concentrations (log-rank test, $\mathrm{p}<0.0001)$. The survival rate of females at maturity

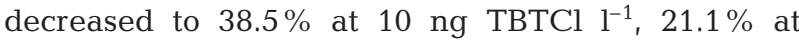
$100 \mathrm{ng} \mathrm{TBTCl} \mathrm{l}^{-1}, 15.6 \%$ at $1000 \mathrm{ng} \mathrm{TBTCl}^{-1}$ and $0 \%$

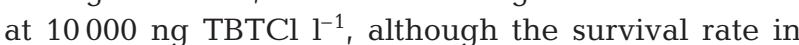
the control was $100 \%$ (Fig. 5). The drastic change in survival rate was observed twice, at 10 to $15 \mathrm{~d}$ and during 35 to 45 d after spawning (Fig. 5). 


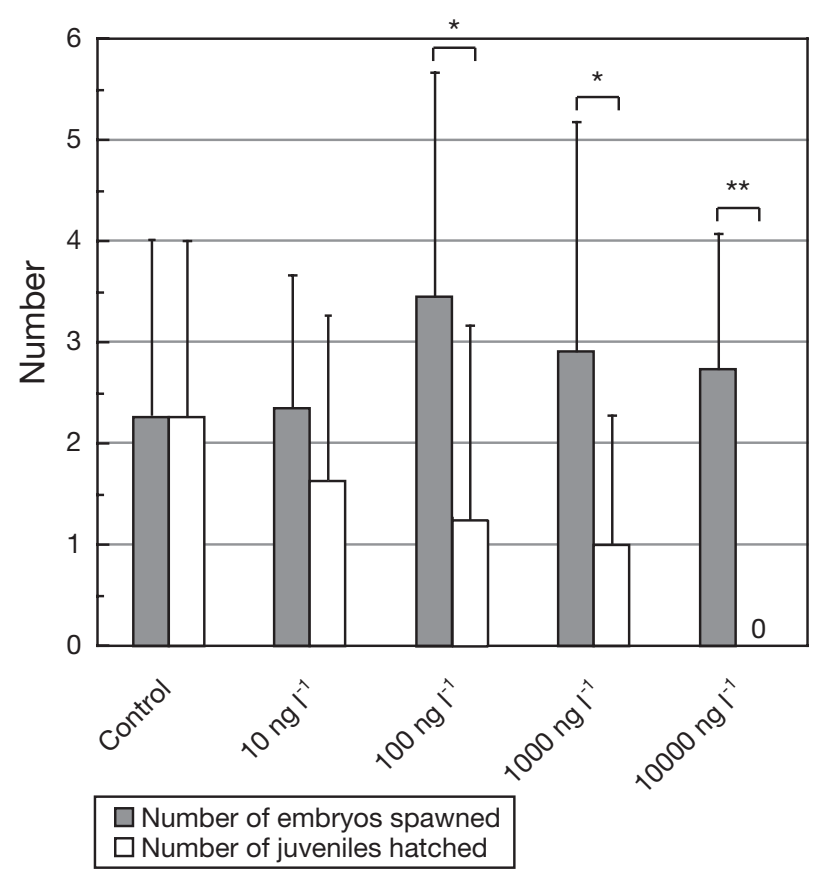

Fig. 4. Comparison between the number of eggs released to the brood pouch and the number of juveniles hatched. Wilcoxon's signed-rank test, ${ }^{*} p<0.05,{ }^{* *} p<0.01$

\section{Sex ratio in the first generation of offspring}

The male and female ratios were 64 and $36 \%$, respectively in the control (Fig. 6), corresponding to previous field observations (Takeuchi \& Hirano 1991). However, as the TBTCl concentration increased, the

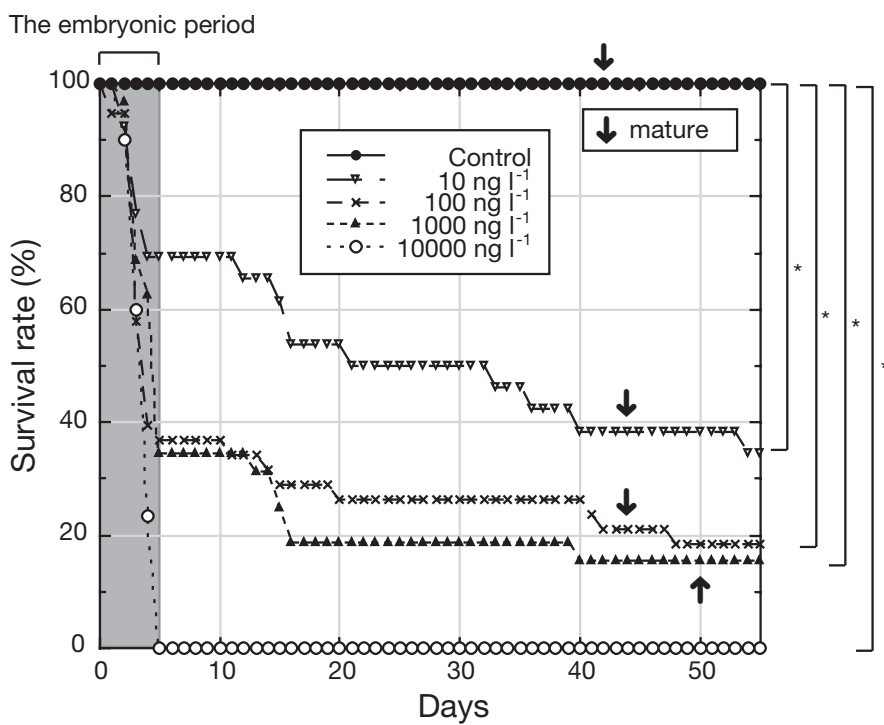

Fig. 5. Changes in the survival rate during spawning and mortality in offspring exposed to TBT during the embryonic stage and thereafter reared in seawater with no TBTCl added. Log-rank test, ${ }^{*} \mathrm{p}<0.0001$ proportion of females increased, i.e. $55.6 \%$ at $10 \mathrm{ng} \mathrm{l}^{-1}$ (44.4\% in males), $85.7 \%$ at $100 \mathrm{ng} \mathrm{l}^{-1}$ (14.3\% in males) and $81.8 \%$ at $1000 \mathrm{ng} \mathrm{l}^{-1}$ (18.2\% in males) (Fig. 6). Significant differences occurred in the sex ratio between the control and $100 \mathrm{ng} \mathrm{TBTCl}^{-1}$ and between the control and 1000 ng TBTCl ${ }^{-1}$ (chi-squared test, $\mathrm{p}<0.01$ ).

\section{Growth and reproduction in the first generation of offspring}

In the present study, no significant differences were found in the body length of each instar and in the time taken for each instar from hatch between the control and each concentration of TBTCl in either males or females (Mann-Whitney $U$-test, $\mathrm{p}>0.05$ ). These results suggest that growth and molting are not inhibited after hatching in response to exposure to $\mathrm{TBTCl}$ in the embryonic period.

In the first mature stage in offspring, oogenesis inhibition and brood loss were observed at $100 \mathrm{ng}$ TBTCl $\mathrm{l}^{-1}$ and $1000 \mathrm{ng}$ TBTCl $\mathrm{l}^{-1}$. Three of 6 mature females exhibited apparent oogenesis inhibition at $100 \mathrm{ng}$ TBTCl $l^{-1}$ and 3 of 5 at 1000 ng TBTCl $l^{-1}$. Brood loss was apparent in 1 of 6 mature females at $100 \mathrm{ng} \mathrm{TBTCl}^{-1}$ and in 2 of 5 at $1000 \mathrm{ng}$ TBTCl $\mathrm{l}^{-1}$. These abnormal ratios during the mature stage increased as the TBTCl concentrations increased, i.e. $0 \%$ at the control and at $10 \mathrm{ng} \mathrm{TBTCl} \mathrm{l}^{-1}, 66.7 \%$ at $100 \mathrm{ng} \mathrm{TBTCl} \mathrm{l}^{-1}$ and $100 \%$ at $1000 \mathrm{ng} \mathrm{TBTCl}{ }^{-1}$.

\section{Sex ratio in the second generation of offspring}

The ratios of males and females in the control and at 10,100 and $1000 \mathrm{ng} \mathrm{TBTCl} \mathrm{l}^{-1}$ were 71.4 and $28.6 \%$, 71.4 and $28.6 \%, 77.8$ and $22.2 \%$, and 66.7 and $33.3 \%$,

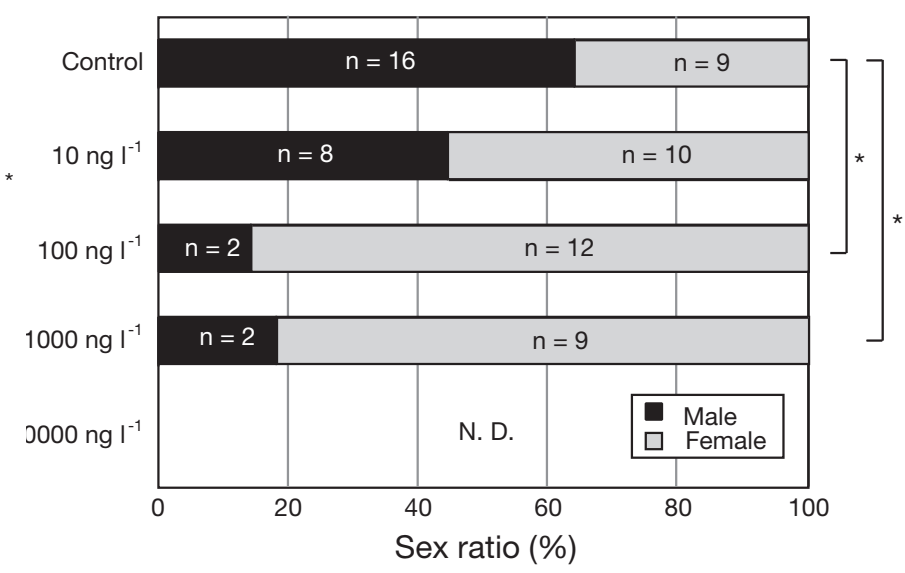

Fig. 6. Sex ratio in offspring of the first generation exposed to $\mathrm{TBTCl}$ during the embryonic stage. Chi-squared test, ${ }^{*} \mathrm{p}<0.05$ 


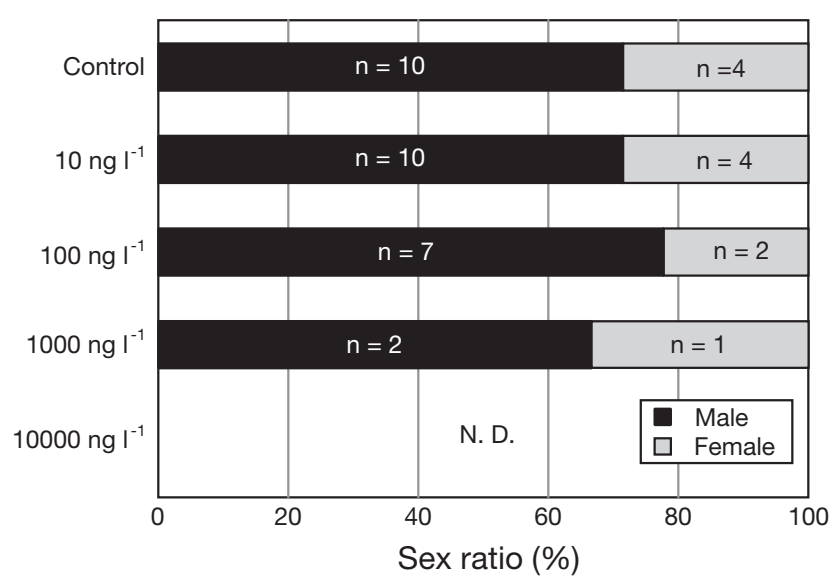

Fig. 7. Sex ratio in offspring of the second generation exposed to $\mathrm{TBTCl}$ during the embryonic stage

respectively (Fig. 7). No significant differences in the sex ratio between control and other concentrations of TBTCl were observed (chi-squared test, $\mathrm{p}>0.5$ ). These results suggest that $\mathrm{TBTCl}$ exposure in the embryonic period does not affect the sex ratio in the second generation.

\section{DISCUSSION}

The present study first demonstrates that the sex ratio in the crustacean changes dramatically even with short exposure to TBT in the embryonic period (5 d). With increases in TBT concentrations, the proportion of females was found to increase to $55.6 \%$ at $10 \mathrm{ng} \mathrm{l}^{-1}$, $85.7 \%$ at $100 \mathrm{ng} \mathrm{l}^{-1}$ and $81.8 \%$ at $1000 \mathrm{ng} \mathrm{l}^{-1}$. However, no significant difference was observed in the sex ratio in response to long-term exposure to TBT at these levels after hatching (50 d) in a previous study (M. Ohji et al. unpubl.). These findings suggest that sex disturbance might be induced during the embryonic stage in the caprellid.

Though the sex ratio in the present study was changed in response to exposure to TBT, the number of females was almost constant (9 to 12) regardless of increases in TBT concentrations (Fig. 6). Accordingly, males seem to have a higher sensitivity to TBT than females. However, the survival rate in response to exposure to TBT has been found to be similar regardless of sex in the juvenile stage (M. Ohji unpubl.). TBT acts as a competitive inhibitor of cytochrome P450mediated aromatase, resulting in an increase in androgens (Spooner et al. 1991, Bettin et al. 1996) and inhibition of androgen elimination (Bettin et al. 1996) in gastropods. These in vivo increases in androgens may result in an androgenization of organisms. Jobling et al. (1996) have shown that some of the breakdown products of alkylphenol polyethoxylate surfactants induce vitellogenesis in male fish as an estrogen receptor-mediated effect. Therefore, receptor-mediated disruption by TBT might occur during the embryonic stage in caprellids. Nevertheless, identification of androgen receptors has not yet been reported in crustaceans. Further experiments are needed to clarify the action of TBT as a hormone disrupter in the endocrine system of caprellids.

Conspicuous reproductive inhibitions such as brood loss and oogenesis inhibition occurred in both parental ovigerous females and ovigerous females of offspring in the first generation, even at nanogram per liter levels of TBT exposure (corresponding to present TBT levels in the coastal environment) during the embryonic stage, although such inhibitions were not apparent in the control in Caprella danilevskii. A similar phenomenon of impairment of egg production has been reported in the copepod Acarita tonsa (Johansen \& Møhlenberg 1987) and in the sea urchin Paracentrouts lividus (Girard et al. 1997, 2000) in response to TBT exposure. The cytotoxicity of TBT often results in an arrest of cellular dynamics, leading to apoptosis (Stridh et al. 1999) or a blocking of cell division (Girard et al. 1997) primarily occurring through an alteration of macromolecular syntheses (Snoeij et al. 1988, Girard et al. 1997) or membrane-mediated processes controlling cell signaling. These processes consist primarily of a disruption of calcium homeostasis (Chow et al. 1992, Matsuoka \& Igisu 1996) or calcium signaling (Corsini et al. 1997, Girard et al. 1997). Girard et al. (1997, 2000) have found that TBT inhibits sea urchin egg cleavage by altering many of the celluar events related to cell division. Furthermore, Girard et al. (2000) have suggested that the inhibition occurs in response to a few hours of TBT exposure and is sufficient to damage the organism during its embryonic life. A similar inhibition related to egg cleavage might occur in the caprellid, resulting in brood loss and oogenesis inhibition in the species. In the present study, impaired reproductive success also occurred in the short-term exposure to TBT during the embryonic stage $(5 \mathrm{~d})$. Therefore, our data suggest that nanogram concentrations of TBT similar to those encountered in coastal waters can directly affect reproduction in the caprellid and that this phenomenon is an environmentally realistic scenario in the coastal ecosystem.

The survival rate decreased drastically as TBT concentrations increased in the present study, with the decrease being found even at $10 \mathrm{ng} \mathrm{l}^{-1}$ (69\%) despite the short exposure period corresponding to the embryonic period in offspring of the first generation. In parental females, the survival rate also decreased at TBT concentrations more than $100 \mathrm{ng} \mathrm{l}^{-1}$ despite movement of females into the no-TBT-added seawater after 
the $5 \mathrm{~d}$ exposure. These results suggest that TBT exposure even at present levels in ambient water and even for a short period might influence the population in the coastal environment.

Acknowledgements. We are grateful to the staff of the Marine Biosystems Research Center, Chiba University, for their support in sample collection and their laboratory experience, and to the staff of the Otsuchi Marine Research Center, Ocean Research Institute, The University of Tokyo, for their support in the collection of seawater. The present study was partially supported by a Grant-in-Aid from the Ministry of Education, Culture, Sports, Science and Technology, Japan (No. 12NP0201).

\section{LITERATURE CITED}

Bettin C, Oehlmann J, Stroben E (1996) TBT-induced imposex in marine neogastropods is mediated by an increasing androgen level. Helgol Meeresunters 50:299-317

Caine EA (1989) Caprellid amphipod behavior and predatory strikes by fish. J Exp Mar Biol Ecol 126:173-180

Chow SC, Kass GEN, McCave MJ, Orrenius S (1992) Tributyltin increases cytosolic free $\mathrm{Ca}^{2+}$ concentration in thymocytes by mobilizing intracellular $\mathrm{Ca}^{2+}$, activating a $\mathrm{Ca}^{2+}$ entry pathway, and inhibiting $\mathrm{Ca}^{2+}$ efflux. Arch Biochem Biophys 298:143-149

Corsini E, Viviani B, Marinovich M, Galli CL (1997) Role of mitochondria and calcium ions in tributyltin-induced gene regulatory pathways. Toxicol Appl Pharmacol 353:136-143

Fuse S (1962) The animal community in the Sargassum belt. Physiol Ecol 11:23-45 (in Japanese)

Girard JP, Ferrua C, Pesando D (1997) Effects of tributyltin on $\mathrm{Ca}^{2+}$ homeostasis and mechanisms controlling cell cycling in sea urchin eggs. Aquat Toxicol 38:225-239

Girard JP, Szpunar J, Pedrotti ML, Pesando D (2000) Toxicity of tri-n-butyltin to sea urchin eggs and larvae: relation to bioaccumulation at the nanomolar level. Environ Toxicol Chem 19:1272-1277

Editorial responsibility: Otto Kinne (Editor),

Oldendorf/Luhe, Germany
Holbrook SJ, Schmitt RJ (1992) Cause and consequences of dietary specialization in surfperches: patch choice and intraspecific competition. Ecology 73:402-412

Jobling S, Sheahan DA, Osborne JA, Matthiessen P, Sumpter JP, Tylor T, Zaman N (1996) Inhibition of testicular growth in rainbow trout (Oncorhynchus mykiss) exposed to estrogenic alkylphenolic chemicals. Environ Toxicol Chem 15: 194-202

Johansen K, Møhlenberg F (1987) Impairment of egg production in Acartia tonsa exposed to tributyltin oxide. Ophelia 27:137-141

Matsuoka M, Igisu H (1996) Induction of c-fos expression by tributyltin in PC12 cells: involvement of intracellular $\mathrm{Ca}^{2+}$. Environ Toxicol Pharmacol 2:373-380

Ohji M, Takeuchi I, Takahashi S, Tanabe S, Miyazaki N (2002) Differences in the acute toxicities of tributyltin between the Caprellidea and the Gammaridea (Crustacea: Amphipoda). Mar Pollut Bull 44:16-24

Snoeij NJ, Bol-Schoenmakers M, Penninkis AH, Seimen W (1988) Differential effects of tri- $n$-butyltin chloride on macromolecular synthesis and ATP levels of rat thymocyte subpopulations obtained by centrifugal elutriation. Int J Immunopharmacol 10:29-37

Spooner N, Gibbs PE, Bryan GW, Goad L (1991) The effect of tributyltin upon steroid titres in the female dogwhelk, Nucella lapillus, and the development of imposex. Mar Environ Res 32:37-49

Stridh H, Orrenius S, Hampton MB (1999) Caspase involvement in the induction of apoptosis by environmental toxicants tributyltin and triphenyltin. Toxicol Appl Pharmacol 156:141-146

Takahashi S, Tanabe S, Takeuchi I, Miyazaki N (1999) Distribution and specific bioaccumulation of butyltin compounds in a marine ecosystem. Arch Environ Contam Toxicol 37:50-61

Takeuchi I, Hirano R (1991) Growth and reproduction of Caprella danilevskii (Crustacea: Amphipoda) reared in the laboratory. Mar Biol 110:391-397

Takeuchi I, Takahashi S, Tanabe S, Miyazaki N (2001) Caprella watch; a new approach for monitoring butyltin residues in the ocean. Mar Environ Res 52:97-113

Submitted: August 21, 2001; Accepted: January 24, 2002

Proofs received from author(s): May 13, 2002 